\title{
The Return of the Prehistoric and the "DeathWish" Of The Tribals IN Mahasweta Devi's Novella, Pterodactyl, Puran Sahay, and Pirtha
}

\author{
JOGAMAYA BAYER \\ Independent Scholar \\ jogamaya.bayer@gmail.com
}

Received: 13-09-2015

Accepted: 30-03-2016

\begin{abstract}
This essay focusses on the cultural violence perpetrated against the adivasis in Mahasweta Devi's novella, Pterodactyl, Puran Sahay, and Pirtha. It illuminates how passive resistance of adivasis in the form of collective mourning upon the appearance of the pterodactyl in their region is misconstrued by others as a "deathwish". The outsiders' misapprehension of adivasis' desperation indicates their indifference to adivasis' culture. The appearance and death of the prehistoric bird is considered by the adivasis to be an omen predicting the extinction of the tribal people and of forthcoming ecological devastation. Although the text embodies the collective melancholia of the adivasis and the author's pessimistic conception of history, it, nevertheless, advocates the responsibility of writers and journalists to disseminate knowledge, thereby helping to usher in a new era.
\end{abstract}

KEYWORDS: adivasis; pterodactyl; cultural violence; collective mourning; passive resistance; deathwish; conception of history

RESUMEN El retorno de lo prehistórico y "el deseo de la muerte" tribal en la novela de Mahasweta Devi, Pterodactyl, Puran Sahay and Pirtha

Este ensayo se centra en la violencia cultural perpetrada contra los adivasis en la novela de Mahasweta Devi, Pterodactyl, Puran Sahay y Pirtha y esclarece cómo la resistencia pasiva de los adivasis, en forma de luto colectivo, es deconstruida por otros como un "deseo de la muerte". La mala interpretación que hacen los forasteros de la desesperación aborigen indica indiferencia ante su cultura. La aparición y la muerte del pájaro prehistórico es considerada por los adivasis como un augurio que predice la extinción de la tribu y la consiguiente devastación del medio ambiente. A pesar de que el texto representa la melancolía colectiva de los adivasis y una concepción pesimista de la historia por parte del autor, aboga, sin embargo, por la responsabilidad de los escritores y periodistas de diseminar el conocimiento, de manera que ayuden a dar paso a una nueva era.

Palabras Clave: adivasis; pterodáctilo; deseo de la muerte; resistencia pasiva; duelo; indiferencia y violencia cultural; concepto de historia

This essay focuses on the cultural violence perpetrated against the adivasis in Mahasweta Devi's novella, Pterodactyl, Puran Sahay, and Pirtha. It illuminates how passive resistance of adivasis 
in the form of collective mourning upon the appearance of the pterodactyl in their region is misconstrued by others as a "deathwish". The outsiders' misapprehension of the adivasis' desperation indicates their indifference to the adivasi culture. The appearance and death of the prehistoric bird is considered by the adivasis to be an omen predicting the extinction of the tribal people and of forthcoming ecological devastation. Although the text embodies the collective melancholia of the adivasis and the author's pessimistic conception of history, it, nevertheless, advocates the responsibility of writers and journalists to disseminate knowledge, thereby helping to usher in a new era.

The plot of the novella involves Puran, a journalist, who has come to write a report on Pirtha, (a fictional tribal block in Madhya Pradesh). He comes at the request of his old friend Harisharan, the Block Development Officer. Upon his arrival, Puran, however, is first received by the Sub-Divisional Officer (SDO) who immediately thematises the Bhopal disaster by establishing its connection with the pollution of water by pesticides and disease in the region. As a matter of fact, the catastrophe was paradoxically caused by the production of pesticides that were supposed to be applied to reduce hunger and death. Although people have been dying in Pirtha for a long time, the Chief Minister of the state refuses to declare it a "famine area." Harisharan's aim is to cause a stir in whatever way he can to draw the administration's attention to the disastrous situation in Pirtha. The people there have concluded that the government has no interest in helping them. Then, a shadow is seen flying over Pirtha. The shadow was painted by Bikhia, a village boy, in the form of a pterodactyl. Nobody outside this community has a viable explanation for the sighting, and outsiders regard it as a figment of the local people's imagination - a myth, like many others told in adivasi oral tradition. The adivasis assume that the disturbed souls of their ancestors have come to warn them that their existence is endangered. Following their own way of explaining miracles, they conclude that nothing can save them now, and therefore they commence a process of collective mourning. Their refusal to move to tribal camps and start a new life is seen by outsiders as an impulse towards self-destruction, a "deathwish" - in Freudian terminology the "death instinct"-now at a climax after the mysterious visit of an extinct bird. For the adivasis, however, leaving the primordial land where their ancestors are buried means tearing up their roots.

On the night of Puran's arrival in Pirtha miraculous things begin to occur. Not only does 96 
it start to rain after a long period of drought, but the prehistoric bird, whose bodiless shadow had only been seen by the villagers, comes into Puran's room to seek refuge. Puran shares this secret with Bikhia, and they both shelter and bury the bird which dies shortly thereafter. Puran returns home having realised that an ancient culture has been destroyed; the aggressive advance of the strong in the name of progress has obliterated the weak - a viewpoint that reflects the author's pessimistic notion of history. The interplay of perceptions of the pterodactyl creates the distinctive dynamic of the story, which is interlaced with facts based on journalistic research.

After his arrival, Puran learns from the SDO that the rainwater flowing down the hillside contained something poisonous. The enteric fever comes from the water, and the SDO is unaware of the water contamination. In his assessment, the state government did not permit a Health Centre in Pirtha as the gas affair in Bhopal preoccupied them more. In a similar vein, Harisharan later remarks, "Bhopal! There's the Union Carbide disaster [...] The state government couldn't be mobilized around such an immense poison-gas disaster, can it be moved about Pirtha?" (Devi, 1995: 147) We read in the "Union Carbide Statement Regarding The Tragedy", "The 1984 gas leak in Bhopal was a terrible tragedy that continues to evoke strong emotions even 30 years later." ("Bhopal Gas Tragedy Information.”). The reference to Bhopal right at the beginning of the novella makes the reader expect a desolate environment and we wonder if the poison that killed the people in Pirtha might have been produced in the Union Carbide plant under normal conditions. However, the shift of focus from Bhopal to the incidents in Pirtha underscores the switch from the "factual" to the "fictional" (Baer, 2011: 180-181).

The repeated references to Bhopal conjure up the eerie atmosphere of the ravaged city, reminding all that the nation is still far from mastering the right techniques to cope with, not to speak of preventing, such ecological calamities now haunting in less spectacular form the impoverished tribal habitations. As a matter of fact, the livelihood of the tribals is seriously jeopardised due to the lack of adequate measures for their environmental protection. However, the text suggests that the tragedy of Bhopal is tied inextricably with the history of the Green Revolution. International agencies influenced the government policy to encourage the use of chemical fertilisers through the Green Revolution, and to promote foreign investment in India's fertilizer industry. (Shiva, The Violence 30, 105).

Nevertheless, more than the misuse of pesticides, other related questions in the text are 
pivotal: why is the prosperity of this Green Revolution not shared fairly? Why is it not in a position to eradicate hunger? "Millions of tons of food grains, green revolutions in Central India, in Orissa, Bihar, West Bengal. Why this poverty then, and why do hundreds of thousands of people leave home mesmerized by labor contractors?" (Devi, 1995: 127). Harisharan and Puran are perplexed why, with the Green Revolution, the prices of food grains have gone up and they wonder who gets the profits. One has to come to the conclusion that the Green Revolution has missed the desired effect for it did not reach those who most needed it, and instead, it pauperised the poor farmers. Moreover, precautionary measures that are necessary in the production of pesticides are lacking and can, at any time, repeat the world's worst industrial disaster that caused so much suffering in Bhopal. Not only do "Survivors continue to exhibit damage to the lungs and eyes," but also, "[r]eproductive effects and increased number of stillbirths and spontaneous abortions were noted in the survivors of the Bhopal, India accident," ("United States Environmental Protection Agency."). The hope of eradication of hunger and poverty that the Green Revolution and birth control programmes evoked turned out to be a delusion as they failed to generate the intended impact. Birth control programmes and new methods of growing more crops through production of fertilizer were conceived to provide people with more food. However, instead of improving life conditions, they have ironically led to population suppression and the loss of human lives by poisoning (Baer, 2011: 191). Here, the text establishes a connection between the misery and extinction of the adivasis on the one hand, and the devastation of nature and the ecology on the other hand. The adivasis are accustomed to life with a light ecological footprint. They are considered to be primitive and excluded from the nation's development; yet their ancient culture shows a way of life that is based on union with nature and not on its conquest. In this context, it is significant what Shiva has to say about the damages done to the coastal ecosystem and the Tsunami of 2004. The indigenous tribes of Andaman and Nicobar who live with a light ecological footprint had the lowest casualties even though they were the closest communities in the Indian subcontinent to the epicentre of the earthquake.

We pride ourselves that we live in an 'information age' and in 'knowledge economies'; yet the knowledge of the 8.9 Richter scale earthquake could not be communicated by the U.S Geological Survey in time for the countries of the Indian Ocean to take appropriate action to save lives... Animals and indigenous communities had the intelligence to anticipate the tsunami and protect themselves (Shiva, 2005: 22). 
The paradoxical birth and population control through starvation for years and the birth of fewer children has not aroused the attention of Pirtha's administration. In this situation, the shadow hovering over Pirtha is endowed with an unusual meaning. It is seen as the soul of their ancestors and the tribals have commenced a collective mourning. In the SDO's view, the tribals need to console themselves with an explanation for their suffering and are, therefore, fabricating stories. The sympathetic officer is well aware that Pirtha is a place of perennial starvation. People there have now accepted their destiny: "How will I make you understand that it is not possible for those tribals to think reasonably, to offer explanations? You will understand them with your urban mentality" (Devi, 1995: 104). The SDO points to a difference of thinking: Puran's urban mentality allows him to think rationally, while the tribals lack the ability to offer realistic explanations. Life in today's world does not permit the officer to believe in the appearance of the bird. However, he realises that the tribals acquiesce to their situation in this manner because they are helpless as everybody is indifferent towards their community even in the time of the famine in Pirtha. "The government doesn't even know that there are human beings in Pirtha," as the Sarpanch, who himself is a tribal, says to Harisharan later (Devi, 1995: 117). What Puran gathers from the SDO and the Sarpanch, is also confirmed by Shankar, one of the tribal protagonists. He recounts in a trance how the strangers came to enslave them and forced them to work as bonded labourer, thus their immiseration began; they destroyed forests and desecrated the graves of the ancestors and built roads, schools, hospitals for their own benefit.

Like the SDO, Puran's friend Harisharan also knows that tribals have always been excluded from their rightful share in national advancements in science and technology. "We have not brought scientific health care to the tribals. If something happens beyond the limits of their knowledge they think of mysterious reasons, divine rage, the witch's glance, and so on" (Devi, 1995: 123). He sees how difficult it is for the tribals to comprehend the whole dimension of their deprivation rationally, and, therefore, tries to explain it with categories they are familiar with. At the same time, Harisharan is also frustrated as he misses the cooperation of the tribals towards the little advancement he can bring. The government does not support him and the tribals are adamant that they would rather die than give up their old ways. He fails to recognise the anger of the tribals who refuse to be deceived in the name of a development that is not genuine and does not consider their interests. So roads are made to bring profit makers who exploit them, as 
Shankar says. Yet, by rejecting their way of reasoning and finding it irrational, Harisharan, who is used to thinking in modern terms, takes their attitude to be a deathwish: "Man, they keep on waiting for a miracle. The modern age has given them nothing, if a miracle can bring some good luck into this intolerable existence! A small miracle, something big! The ancestors' shadow had brought a kind of news to them, as a result of which whole villages were awash with death-wish" (Devi, 1995: 144-145).

We are accustomed to thinking that all living substance is bound to die from internal causes. As Freud points out, "It is certainly not a primaeval belief. The notion of 'natural death' is quite foreign to primitive races; they attribute every death that occurs among them to the influence of an enemy or of an evil spirit" (Freud, 1955: 45). In a similar manner, the fear of the tribals on seeing a shadow causes a premonition that the soul of the forefathers has come to announce their imminent end.

One of Freud's achievement in psychoanalysis is to untangle the complexities of human beings' drive towards pleasure and unpleasure, and the inherent life and death instincts. In Beyond the Pleasure Principle, Freud elaborates upon the death instinct of human beings. He explains, "[...] an instinct is an urge inherent in organic life to restore an earlier state of things which the living entity has been obliged to abandon under the pressure of external disturbing forces; that is, it is a kind of organic elasticity, or, to put it another way, the expression of the inertia inherent in organic life" (Freud, 1955: 36). He gives examples from animal life to confirm that instincts are historically determined. Certain fishes cover long distances to return to the localities in which their species formerly resided to deposit their spawns. Migratory flights of some birds can be similarly explained. This phenomenon attests to his hypothesis "that all instincts tend towards the restoration of an earlier state of things" (Freud, 1955: 36-37). He therefore justifies a dualistic view between life and death instincts. Freud further establishes an interconnection between our conscience anxiety and the death instinct, and attributes the function of conscience to the super-ego. He then calls the ego ideal or super-ego the heir of the Oedipus complex and underlines its links with our phylogenetic acquisition - our archaic heritage. When the role of father is substituted with teachers and other authority figures, their orders and prohibitions continue to exercise moral censorship in the ego ideal in the form of a conscience (Freud,1961: 36-37). "The ego reacts with feelings of anxiety (conscience anxiety) to the 100

Indi@logs, Vol 4 2017,pp.95-109, ISSN 2339-8523 
perception that it has not met the demands made by its ideal, the super-ego [...] The super-egothe conscience at work in the ego- may then become harsh, cruel and inexorable against the ego which is in its charge" (Freud, 1961: 167). Thus, for Freud, the Oedipus complex turns out to be the source of our individual ethical sense, our morality. He defines the super-ego as "a pure culture of the death instinct" with its critical surveillance of the ego (Freud, 1961: 53). In a trance Shankar articulates the adivasis' sense of guilt for having done something wrong, which has displeased their forefathers: "The forefathers have been insulted, we could not protect their dignity. Now our life and death are not in our hands" (Devi, 1995: 129).

The collective melancholia of the adivasis reflects their anxiety that they have failed to keep the dignity of their ancestors. The curse of the ravaged forest and their ancestors' soul have taken the form of the pterodactyl to caution them of their imminent obliteration. Furthermore, the text establishes an interconnection between the extinction of the adivasis, the depletion of the forests and ecological devastation: "We failed to give peace to the ancestors. We are coming to an end, rubbed off the soil. And so the unquiet soul casts its shadow and hovers [...] This is surely the ancestors' spirit! This is surely the curse of the ravaged land, village, field, home, forest! Now no one can save us. Now we are all unclean, in mourning" (Devi, 1995: 120). A correlation exists between the adivasis' sense of guilt and suffering, and between their mourning and passive resistance- a part of India's political cultural heritage. Gandhi appealed to the conscience of his countrymen for their lack of unity as it created circumstances that gave the East India Company its control over India (Gandhi: 36) He exhorted them to expiate for their sins and to reform themselves. According to Gandhi, this was a time for repentance, expiation and mourning. They would become free only through suffering (Gandhi: 97). In Hind Swaraj or Indian Home Rule Gandhi defines passive resistance as follows:

The fact is that, in India, the nation at large has generally used passive resistance in all departments of life. We cease to co-operate with our rulers when they displease us. This is passive resistance... You may, if you like, cut us to pieces. You may shatter us at the cannon's mouth. If you act contrary to our will, we shall not help you; and without our help, we know that you cannot move one step forward. (Gandhi: 78, 94)

Harisharan's use of modern psychoanalytic terms to explain the cause of their suffering neither acknowledges the passive resistance of the tribals nor attributes necessary importance to it. Harisharan presumes that the deathwish of the tribals is irrational. While depriving them of the 
capacity of reasoning, he observes that the tribals are actually not ignorant of the concrete facts that have led them to their state of crisis and desperation in which they now find themselves. Shankar's accusation that they have been deprived of all their rights and pushed more and more out of their habitations voice the grievance of a vast population: "The government doesn't want that we live. That's why they don't give us any help" (Devi, 1995: 129). Even when Shankar tries to make him understand that these people have lost faith in the administration and are convinced that no relief will ameliorate their condition, he is disappointed to see that Harisharan cannot realise it. When a welfare organisation wants to take pictures of its providing relief to the suffering inhabitants who are unwilling to let them be photographed in this condition, Shankar speaks out their anger, "Relief. Take relief, let 'em make fillims. We are hungry, naked, poor. That will be known on the fillims. But the fillim won't say who made us hungry, naked, and poor. We don't beg, don't want to beg, will people understand this from those pictures?" (Devi, 1995: 177). There is an unfathomable gap between modern India and their world, which brings the breach of communication between Harisharan and the tribals to a climax. Although Puran tries to contradict the approach that they are inhabitants of two different worlds and makes real efforts to overcome this distance by trying to live as closely as possible to the tribals, he gradually understands that he cannot reach Shankar's people just by eating little or sleeping on grass mats. Nevertheless, this great gulf makes it all the more necessary to investigate how this gap can be negotiated.

At the end of the novel, Puran's report complements the journalistic facts provided by the narrator until then:

The state government will not allow us to say "famine," because then it will be revealed that: ...[m]any officers, politicians, and contractors are implicated in this. This is why it is so hard to get food by government channels and help had to be accepted from a non-government organization [...] They will not leave the hills. Whether they eat or starve, it is the symbol of their near-extinct ethnic being. (Devi, 1995: 189)

Once their emotional ties to their land, which contains the burial grounds of their forefathers and is a part of their socio-cultural heritage, are broken, they will lose all sense of belonging (Singh, 2002: 221). That Puran's effort to come closer to these people and understand them was not completely meaningless-Puran definitely had more access to their thinking than anybody 
else - is verified when Shankar expresses this disillusionment of the whole community: "But we will not leave Pirtha [...] If they want to give us aid, let them give it to us here [...] No we won't go anywhere. Let them give us our dues here [...] If not let them forget, let them forget us. At most we'll die, nothing worse can happen" (Devi,1995: 194). According to Gandhi, passive resistance is a method of securing rights by personal suffering that does not inflict pain on others (Gandhi 74). This moral power of the villagers is juxtaposed with the cultural violence that the country uses by ignoring their right to their ancestral home.

While the inclination of the villagers to stick to their ancestral place is considered by modernity as a 'deathwish', it would appear that social welfare is their only hope for survival. When, in a dialogue, Harisharan tries to draw Puran's interest in Kausalji's welfare organisation by describing it as a well-organised one, Puran decisively refuses to accept that this could be the solution for Pirtha, for they need long lasting help, which demands a stable solution to their problems. Kausalji's scheme to get back the tribal land from the government is tied up with his demand that the tribals come down from the hills. They will farm and plant trees with plenty of water in a housing development that he plans to build for them. He makes it clear: "If they want to live on hills then we have to bring the roads up and give them land down below. Ask them to forget such unrealistic matters. Ask them to cooperate" (Devi, 1995: 151). Behind this wellmeaning offer, he has actually forged a more lucrative marketing strategy for himself. So, he advises Harisharan not to help them by digging wells: "If you can move them, and plant some more trees, this spot with the river, the hills and the trees will make an excellent picnic area" (Devi, 1995: 151). The lack of uprightness of his design is exposed through the narrator's suggestive questions: "In the India of the future, will they be preserved as endangered species or mingle in the mainstream?" (Devi, 1995:151). However, Harisharan has no other alternative than to work with Kaulasji, who has power and influence. Harisharan sees that these volunteer organisations can at least do some work, while the government has failed to assume responsibility. It is very obvious to him that the villagers cannot survive if they do not leave. At this point of the text, journalistic informations provided by the narrator reminds the reader of facts that s/he may not be aware of:

Foreign money infiltrating by way of voluntary organizations in the name of welfare, is that unknown to the central government or at the state level? They have to accept this, because in spite of their hundreds of thousands of projects and tens of millions of 
rupees and a few hundred thousand government employees and Panchayats nothing reaches the real recipient (Devi, 1995: 169).

In an interview with Spivak, Devi explains how she evaluates the work of welfare organisations. She criticises the policy of international non-governmental organisations that provide money and expertise to certain places. This arouses resentment in others. Besides that, this type of help seldom reaches the right recipients. As the government is absolutely reliant on their money, the state governments must accept their work: "I've seen many places, many organizations, where I disagree with the purpose with which the money is given, and I am angry and disgusted" (Devi, 2003: xviii).

By way of reinterpreting Verrier Elwin's cultural ecology in central India, Archana Prashad explains how welfare programmes can pave the way to competitive communalism. As historically observed, the beginning of greater dependence on welfare measures - many of which were initiated by Christian missions - started with the crisis of tribal life that had intensified under the impact of colonial land and forest policies. Gradually, welfare programmes led to rivalry among communal groups, as service providers competed with one another in their attempt to integrate the tribal people. Thus, already from the 1930s, competition started to grow among welfare organisations. The missionaries, who were no longer the sole providers of welfare, now faced opposition from Hindu nationalists, the Congress government, and other social workers (Prasad, 2003: 92-99). Prashad critiques that the situation has not changed much since then, and tribals are still victims of rivalry between communal groups. Prasad's critique appears to be absolutely justified when we consider the recent outbreak of violence to which the adivasis were exposed to because of antagonism between the fundamental Hindus and Christian missionaries. She stresses that, "The fight against communal politics must, therefore, include the evolution of a new strategy for the tribal economies - a strategy that replaces the welfare model with a creative 
strategy that promotes the development of the productive resources of the tribal economy" (Prasad, 2003: 101).

Devi's pterodactyl, an "unearthly terror" (ashariri, literally "bodiless", atanka) with a horrible toothless mouth, manifests demonic traits in Bikhia's painting. It is not seen by anybody except for Puran and this village boy (Devi, 2004: 229). Others have only seen its shadow. After perceiving this bad omen, the adivasis have fallen into collective melancholia and started mourning.

Significantly, Lazarus juxtaposes the gaze of the angel of history in the ninth "thesis" of Walter Benjamin's Thesis on the Philosophy of History, a much discussed work of Benjamin with that of Devi's pterodactyl. Here Benjamin refers to a picture by Paul Klee called Angelus Novus that he himself had possessed. In the picture, an angel is depicted with his eyes and mouth open and wings outstretched, and his face turned towards the past. He seems to stare at something from which he wants to distance himself.

The Angel of History must look just so [...] Where we see the appearance of a chain of events, he sees one single catastrophe, which unceasingly piles rubble on top of rubble and hurls it before his feet. He would like to pause for a moment so fair [...], to awaken the dead and to piece together what has been smashed. But a storm is blowing from Paradise, it has caught itself up in his wings and is so strong that the Angel can no longer close them. The storm drives him irresistibly into the future, to which his back is turned, while the rubble-heap before him grows sky-high. That which we call progress, is this storm. (Benjamin, 2005)

Lazarus specifically draws our attention to the non-human gaze of the angel as well as that of the pterodactyl. Benjamin's angel would like to wake the dead, but fails to fulfil this task. Similarly, having failed to transmit a message, the ancestors' soul disappears in immateriality (Lazarus, 2013: 524-527).

Puran is witnessing his own futility. Having seen history from beyond pre-history, continental drift, seasonal changes after much geological turbulence, the advent of the human race, primordial history, the history of the ancient lands, the Middle Ages, the present age, two World Wars, Hiroshima-Nagasaki, holding under its wing this entire history and the current planetary arms race and the terror of nuclear holocaust, it came to give some sharply urgent news. Puran, a modern man, could not read the message in its eyes. Nothing could be known, can be known. One has to leave finally without knowing many things one should definitely have known. Seeing that Puran had understood nothing, its eyes were closed since yesterday. (Devi, 1995: 180) 
In an essay titled "Walter Benjamin and His Angel," published in 1972, Gershom Scholem offers an interesting interpretation of a brief prose piece by Benjamin, "Agesilaus Santander." In this essay, Scholem argues that the apparent luminosity of the figure of the angel, which occupies a special place in Benjamin's ideas, hides the demonic traits of "Angelus Satanas" (Agamben, 1999: 138). Scholem's reading links the figure of the angel in "Agesilaus Santander" with the angel of history in the previously mentioned Thesis on the Philosophy of History. He explains how Benjamin's personal angel here has turned into the angel of history. Scholem detects in this angel a melancholy figure "wrecked by the immanence of history." It is a "melancholy, indeed desperate, view of history." Benjamin would thus have wanted, following Jewish mysticism, to see the angel as one who fails in his task, while the Messiah makes whole the catastrophe of history ("piece together what has been smashed").

In Agamben's view, Scholem's reading casts a melancholic light on Benjamin's reflections on the philosophy of history, in which the angel plays a redemptive role. It contradicts Benjamin's text that endows the figure of the angel with the idea of happiness. Agamben questions, if Benjamin's angel is "a melancholy figure, wrecked by the immanence of history" why is it said of him in "Agesilaus Santander" that on his return "he takes a new human being along with him"? He rectifies Sholem's interpretation as it contrasts with another text by Benjamin, the Theologico-Political Fragment which is of special significance to this problem. The fragment refutes Scholem's arguments and underlines that the order of happiness-and not the messianic order — prevails over the profane historical order (Agamben, 1999: 144). Agamben indicates that Benjamin's concept of happiness is interrelated with his concept of redemption. He clarifies that what is important is that "[...] in historical redemption what happens in the end is what never took place [...] But this-what has never happened -is the historical and wholly actual homeland of humanity" (Agamben, 1999: 158-159).

In Mahasweta's text, this shadow of a real existing bird of prehistory ties the whole span of history beginning with when mankind did not exist, and forebodes its probable end in the nuclear holocaust. The appearance of this bird does not evoke any hope but an unuttered message of decay.

What do its eyes want to tell Puran? [...] We are extinct by the inevitable natural geological evolution. You too are endangered. You too will become extinct in nuclear explosions, or in war, or in the aggressive advance of the strong as it obliterates the 
weak, which finally turns you naked, barbaric, primitive, think if you are going forward or back. (Devi, 1995: 157)

The authorial voice suggests a conception of history that does not understand history as a linear progression, "[...] look at history, the aggressive civilization has destroyed itself in the name of progress, each time" (Devi, 1995: 196). The aggressive advance of the strong in the name of progress obliterates the weak and is in fact retrogression. The tribal world has been destroyed. The miracle of the pterodactyl is a part of their unwritten history. This is a part of their resistance. (Devi, 2003: x-xi).

Lazarus points to a link between "the sustainability of human life itself and recovery of the forms of aboriginal sociality" that the text indicates. However, the task of establishing this link lies "not with those who have been displaced, dispossessed and marginalised by "India" (local avatar of the "modern"), but with the likes of Puran Sahay and, more generally, ourselves (her presumptive readers)" (Lazarus, 2013: 528).

Obviously, Puran witnesses the cultural violence towards the inhabitants of Pirtha, and the necessity to represent their cause is manifested through the deploying of his pen, “ $[\ldots]$ let Puran be able to keep his faith in the pen. He is not a tribal [...] How can he have faith in their faith? Puran must keep unshaken his faith in paper, pen and the printing machine" (Devi, 1995: 185-186). Puran knows his work as a journalist gives him power, but also responsibility to usher in a change of mind through his writing. While the pterodactyl of history fails in its task to transmit an urgent message it wanted to convey, it has now become, as Puran realises, a task of writers and journalists to accomplish it.

This essay has demonstrated how the passive resistance of the adivasis in the form of collective mourning upon the appearance of the pterodactyl is misconstrued by outsiders as a "deathwish". This misapprehension of the tribals' desperation at their poor conditions and their gradual obliteration is to be viewed in light of the Indian establishment's indifference to their cultural difference. The appearance and death of the prehistoric bird is considered to be a premonition of the extinction of the adivasis and of the ecological devastation of their environment. Although the text embodies the collective melancholia of the adivasis and reflects their enormous suffering and the author's pessimistic conception of history, it, nevertheless 
advocates the responsibility of writers and journalists to disseminate knowledge, thereby helping to usher in a new era.

\section{WORKS CITED}

AGAMBEN, GIORGIO (1999). "Walter Benjamin and the Demonic: Happiness and Historical Redemption", in Daniel Heller-Roazen (ed. and trans). Potentialities: Collected Essays in Philosophy, Stanford, California: Stanford University Press: 138-159.

BAER, BEN CONISBEE (2011). "Terodacktyl Apocalypse: Writing Catastrophe in Mahasweta Devi's Pterodactyl, Puran Sahay, and Pirtha", In: Nick Heffernan and David A. Wragg (eds). Culture, Environment and Ecopolitics, Newcastle upon Tyne: Cambridge Scholars Publishing: 177-199.

BENJAMIN, WALTER (2005). On the Concept of History, Dennis Redmond (trans). http://www.efn.org/ dredmond/Theses_on_History.html accessed 18 October 2014.

“Bhopal Gas Tragedy Information.” http://www.bhopal.com/ accessed 08 October 2014.

DEVI, MAHASWETA (1995). "Pterodactyl, Puran Sahay, and Pirtha", In: Gayatri Chakravorty Spivak (trans). Imaginary Maps: Three Stories by Mahasweta Devi, New York and London: Routledge: 95- 196.

--- (2003). “'Telling History': An Interview with Mahasweta Devi”, In: Gayatri Chakravorty Spivak (trans). Chotti Munda and His Arrow, MA USA: Blackwell Publishing: ix-xxiii.

---(2004). “Terodactil, Puran Sahay O Pirtha”, Mahasweta Devi Rachanasamagra. Vol. XV, Kolkata: Dey's Publishing: 225 - 306.

FREUD, SIGMUND (1955). "Beyond the Pleasure Principle", In: James Strachey (ed. and trans). The Standard Edition of the Complete Psychological Works of Sigmund Freud, Vol. 18, London: The Hogarth Press: 3-64.

--- (1961). "The Ego and the Id", In: James Strachey (ed. and trans). The Standard Edition of the Complete Psychological Works of Sigmund Freud, Vol. 19, London: The Hogarth Press: 3-66.

---(1961). "The Economic Problem of Masochism", In: James Strachey (ed. and trans). The Standard Edition of the Complete Psychological Works of Sigmund Freud, Vol. 19, London: the Hogarth Press: 157-70.

GANDHI, M. K. Hind Swaraj or Indian Home Rule, Ahmedabad: Navajivan Publishing House. http://www.mkgandhi.org/ebks/hind_swaraj.pdf accessed 05 September 2015. 
LAZARUS, NEIL (2013). "Epilogue: the pterodactyl of history?”, Textual Practice, Vol. 27, No 3, 523-536. DOI: 10.1080/0950236X.2013.784031.

PRASAD, ARCHANA (2003). Against Ecological Romanticism: Verrier Elwin and the Making of an Anti-Modern Tribal Identity, New Delhi: Three Essays Collective.

SINGH, K.S. (2002). Birsa Munda and His Movement 1872-1901: A Study of a Millenarian Movement in Chotanagpur, Calcutta: Seagull Books.

SHIVA, VANDANA (1991). The Violence of the Green Revolution: Third World Agriculture, Ecology and Politics, London and New Jersey, Penang: Zed Books Ltd., Third World Network, 1993.

---(2005). “The Lessons of the Tsunami”, The Ecologist, Vol. 35, No 2, March: 21-24.

"United States Environmental Protection Agency: Technology Transfer Network." Air Toxics Web Site. http://www.epa.gov/ttn/atw/hlthef/methylis.html accessed 04 October 2014.

JOGAMAYA BAYER is an independent scholar. She has published on postcolonial literature and theory. She is the author of Transgressing Boundaries: Essays on Postcolonial Literature (London: Roman Books 1913). Her publications include "Going Away/Coming Home: Searching for a Fixed Point in Postcolonial Indian Writing," in Experiences of Freedom in Postcolonial Literatures and Cultures, eds. by Annalisa Oboe, Shaul Bassi (New York: Routledge, 2011). 